\title{
Selenium in natural environment and food chains. A Review.
}

\author{
O.I. Sobolev' ${ }^{1}$, B.V.Gutyj ${ }^{2}$, S.V. Sobolieva ${ }^{3}$, O.O. Borshch ${ }^{1}$, V.M. Nedashkivsky', \\ L.M. Kachan ${ }^{1}$, P.M. Karkach ${ }^{1}$, N.V. Nedashkivska ${ }^{1}$, O.A. Poroshinska', L.S. Stovbetska', \\ A.A. Emelyanenko', S.S. Shmayun ${ }^{1}$, Z.A. Guta ${ }^{2}$ \\ ${ }^{1}$ Bila Tserkva National Agrarian University. Bila Tserkva, Ukraine \\ ${ }^{2}$ Stepan Gzhytskyi National University of Veterinary Medicine and Biotechnologies. Lviv, Ukraine \\ ${ }^{3}$ Bila Tserkva Institute of Continuous Professional Training. Bila Tserkva, Ukraine
}

\author{
*Corresponding author E-mail: bvh@ukr.net \\ Received: 13.08.2020. Accepted 18.09.2020
}

\begin{abstract}
The analytical review attempts to summarize the results of numerous scientific research conducted by scientists around the world on selenium scattering and accumulation in natural environment, with considerable attention paid to the concentration of this trace element in soils, natural waters and plants. It is shown that selenium content in agricultural products is caused by the processes of physico-chemical and biogenic migration of this element in the biogeochemical food chain. According to the modern classification of trace elements, which is based on their biological significance for living organisms, selenium belongs to the vital group or biogenic elements. As a biotic element, it has unique physicochemical and biochemical properties and with adequately absorbed into the human body has a positive effect on a number of physiological processes. Various research shows that the majority of the world population (except in some regions) today consumes less selenium with the food than necessary and its consumption decreases every year. Insufficient selenium intake in the human body (less than 15-30 $\mu \mathrm{g} / \mathrm{day}$ ) leads to the development one of the hypomicroelementosis - hyposelenosis. Selenium deficiency is considered as a possible etiological factor in some cardiovascular, cancer, osteoarticular and neurodegenerative diseases that threaten to human life. Providing the human body with selenium in optimal amounts is one of the important conditions of nutrition. A number of countries have developed recommended selenium intake standards for the adults, which range from 55 to $120 \mu \mathrm{g} /$ day. We can calculate the physiological need for selenium in children and adolescents by extrapolation. The most safe and effective way to maintain the necessary level of selenium for the human body can be achieved only through the poultry and livestock products by mandatory introduction of premixes containing highly effective biologically available selenium forms into animal feed. This will ensure a relatively high level of trace element in meat, eggs, and milk and would eliminate the cases of toxicosis in human population due to buffer effect of animal tissues.
\end{abstract}

Keywords: selenium, concentration, soil, water, feed, poultry products, scarce selenium, human need

\section{Introduction}

The history of Selenium discovery

Selenium occupies a special place among seventeen trace elements that are currently recognized as vital for human body, animals and poultry (Prashanth et. al., 2015; Martyshuk et al., 2020).

As a biotic element, it has an interesting history and that history is far from over. The element was discovered by the outstanding Swedish chemist Jens Jacobi Berzelius in collaboration with Hoplib Gan in 1817. The new element had a chemical similarity to tellurium discovered by German chemist Martin Heinrich Klaproth in 1798 and named after the Earth (Tellus - Earth). By analogy, J. Berzelius named new element using the Greek word "Selene" which means "Moon" (as the Moon is a satellite of the Earth and selenium is a satellite of tellurium) (Boyd, 2011). The first mention in literature about biological role of selenium dates back to 1842, when it was found that Bacillus ferreus is able to restore selenium compounds. In later works (1885), it was shown that plants are able to absorb selenium dissolved for them in water. Further research have confirmed the influence of selenium on oxidative processes of cellular metabolism (Gromova \& Gogoleva, 2007). Understanding the role of selenium in animal nutrition came in 1931, when it was discovered that a number of causes of endemic diseases in cattle, pigs and poultry on territory of the Great plains of America was their consumption of plants and grains with excessive selenium content. The signs of selenium poisoning were: weight loss, hair loss, joints damage, bones, hooves and skin, vision loss(animals stumbled), paralysis and, as a result, death from exhaustion. Similar symptoms were described in horses in 1856. However, at that time they were not associated with selenium toxicosis (Schrauzer \& Surai, 2009). Subsequently, territories with excess selenium in 
soils and plants and cases of selenium toxicosis in animals were established in Canada, Ireland, Colombia, Australia, England, the CIS countries and other countries.

Until 1957, selenium was considered exclusively as a toxic trace element. Only in 1957 the scientists K. Schwarz and C. Foltz from National Institutes of Health (USA) identified vital importance of selenium, demonstrating in classical experiments that exactly this trace element prevents the development of necrotic liver degeneration in rats. This was the beginning of using selenium compounds to treatment of white muscle disease in sheep and cattle, alimentary hepatitis of pigs, exudative diathesis, poultry encephalomalacia and other diseases. In 1974, the US Food and Drug Administration (FDA) approved the addition of selenium to animal and poultry diets in the form of sodium selenite in an amount of $0.1 \mathrm{mg} / \mathrm{kg}$. After 5 years, the FDA revised the maximum allowable level of selenium inclusion in feed and it raised to $0.3 \mathrm{mg} / \mathrm{kg}$. Later, thanks to research of many scientists, this level was raised to $0.5-1.0 \mathrm{mg} / \mathrm{kg}$ depending on the country of the world (Arnér, 2011). In the following years, domestic and foreign scientists have carried out a significant amount of work to further study the biological role and mechanism of action of selenium on a living organism.

\section{Physico-chemical properties of selenium}

It is probably impossible to get a complete scientific understanding of the biological effect of selenium on a living organism and the features of its migration in natural environment without taking into account its physical and chemical properties and position in the periodic table of D.I. Mendeleev. Selenium is the $34^{\text {th }}$ chemical element in the fourth row (the main subgroup) of the periodic table of the elements, with an atomic mass is $78.963 \mathrm{Da}$, nonmetal. Atomic and covalent radius are 103 and 0116 pm, respectively. The ionization potential of the first electron is $941.0 \mathrm{~kJ} \mathrm{~mol}^{-1}$, the second electron is $2045.0 \mathrm{~kJ} \mathrm{~mol}^{-1}$, and the third electron is $2973.7 \mathrm{~kJ} \mathrm{~mol}^{-1}$. The electronegativity according to Pauling is 2.55 . Melting point is $494 \mathrm{~K}, 221^{\circ} \mathrm{C}$ Boiling point is $958 \mathrm{~K}, 685^{\circ} \mathrm{C}, 1265^{\circ} \mathrm{F}$. The density is $4.79 \mathrm{~g} / \mathrm{cm}^{3}$. The number of protons (electrons) are 34 , neutrons are 45 . Color is gray with a metallic luster (Perrone et. al., 2015).

The electronic formula of selenium has form $1 s^{2} 2 s^{2} 2 p^{6} 3 s^{2} 3 p^{6} 3 d^{10} 4 s^{2} 4 p^{4}$. The electron levels (shells) of selenium - K, L, M, and $\mathrm{N}$ have $2,8,18$, and 6 electrons, respectively. The outermost electron shell of selenium atom $\left(4 \mathrm{~s}^{2} 4 \mathrm{p}^{4}\right)$ includes six electrons, which its determines metalloid properties. In the first two p-electrons, the spins are paired and in the last two are unpaired which determines paired valence $(+2,+4,+6)$ and the ability of selenium atoms to form $\mathrm{Se}_{2}$ molecules or chains of Sen atoms. The latter ones are in turn can be closed in ring Ses molecules. The presence of selenium in four energy levels and size of its atomic and covalent radius indicate a decrease in energy demand required for the separation of external electrons, which reduces the ionization and electronegativity potentials (Rayman, 2008; Glinka \& Ermakov, 2009).

Selenium is able to change the composition and structure of its molecule depending on external conditions. The diversity of Selenium molecular structure determines the existence of two allotropic modifications of the element: amorphous (powdery, colloidal, glassy) and crystalline (monoclinic $\alpha$ - and $\beta$-form, hexagonal $g$-form). Elemental selenium (any modification) is homochain inorganic polymer. The ability of selenium to shift electron pair towards one of the atoms during the formation of certain substances determines its degree of oxidation: $-2 ; 0 ;+2 ;+4 ;+6$. All degrees of oxidation element are usually found in nature, with the exception of +2 state. In compounds, selenium can be negatively divalent (selenide, Se ${ }^{2-}$ ) and positively tetravalent (selenite, $\mathrm{SeO}_{3}{ }^{2-}$ ) and hexavalent(selenate, $\mathrm{SeO}_{4}{ }^{2-}$ ) (Grinvud \& Jernsho, 2008).

\section{Natural forms of selenium}

Selenium in nature exists in inorganic and organic forms. Most often, inorganic selenium can be found in the form of selenite, selenate, selenide, or in elementary state $\left(\mathrm{SEO}_{\mathrm{O}}\right)$. The main natural forms of organic selenium are selenomethionine $\left(\mathrm{CH}_{3}-\mathrm{SeCH} \mathrm{C}_{2}\right.$ $\left.\mathrm{CH}_{2} \mathrm{NH}_{2}-\mathrm{COOH}\right)$ and selenocysteine $\left(\mathrm{HSeCH}_{2}-\mathrm{CHNH}_{2}-\mathrm{COOH}\right)$, where it is in the state of Se ${ }^{2-}$ oxidation (Sigai, 2007).

There are more than 50 microminerals, including selenium. It is mainly found in sulphide ores, uranium-vanadium, molybdate, phosphorite and sulfur deposits. Selenium forms rare minerals, which are represented mainly by such forms: lead selenate(kerstenit), sodium and potassium; lead selenite (molybdenite), copper (chalcomenite) and nickel (ahlfeldite); lead selenide (clausthalite, zorgite), copper (klockmannite, berzelianite), silver (naumannite, eucairite, crookesite) and mercury (tiemannite). In addition, there is native selenium (Reimann \& Caritat, 1998; Ralston et. al., 2009). In nature, a significant number of selenium isotopes are known, six of which are stable, with the following prevalence: ${ }^{74} \mathrm{Se}(0.87 \% \mathrm{by} \mathrm{mass}),{ }^{76} \mathrm{Se}(9.02 \%),{ }^{77} \mathrm{Se}$ $(7.58 \%),{ }^{78} \mathrm{Se}(23.52 \%),{ }^{80} \mathrm{Se}(49.82 \%)$ and ${ }^{82} \mathrm{Se}(9.19 \%)$, and the remaining twenty-six are radioactive, with different half-lives, in the range of mass numbers from 64 to 95 (Gross et. al., 2012). Although selenium radioisotopes are not found in natural conditions, some of them can be obtained by neutron activation (Reilly, 2006; Hamidatou et. al., 2012).

The mass fraction of selenium in the earth's crust is on average $6-10^{-5} \%$, soils are $1-10^{-6}$, sea water are 4-10-7, fresh water are $3-10^{-6}$, plants are $1-10^{-7} \%$. Low concentrations of selenium were found in the air less than $10 \mathrm{ng} / \mathrm{m}^{3}$ (Karnauhov et. al., 2003 ). The concentration of trace element in rainwater ranges from 0.1 (Sun et. al., 2003) to $13 \mu g / l$ (Calabrese, 2009) depending on geographical region.

There is no doubt that the movement of selenium in the biosphere occurs according to the scheme: soil - water - plant - animal - human (Winkel et. al., 2015). This sequential migration path forms a biogeochemical chain, which we will trace. The distribution of selenium in soils, plants, livestock and poultry products in different regions of the Earth indicated a great variety (El-Ramady et. al., 2015; Kieliszek \& Błażejak, 2016; Sychov et al., 2017; Komlyk \& Brygadyrenko, 2019; Kovalchuk et al., 2019; Brygadyrenko et al., 2019; Darmohray et al., 2019).

\section{Selenium in soils}

Depending on the type of soil-forming rocks, oxidation-reduction and alkali-acid conditions selenium content in soils can vary from $110^{-6}$ to $110^{-3} \%$ (Ermakov, 1995). Its content in igneous rocks occasionally exceeds of $0.05 \mathrm{mg} / \mathrm{kg}$. In sedimentary rocks, selenium is associated with clayey fraction and therefore its concentration is higher from 0.05 to $0.60 \mathrm{mg} / \mathrm{kg}$. In native sulfur and sulfide minerals, its concentration can reach $200 \mathrm{mg} / \mathrm{kg}$. However, in sulfur deposits of sedimentary origin, the selenium content is usually lower than $1 \mathrm{mg} / \mathrm{kg}$ (Kabata-Pendias \& Mukherjee, 2007). The lowest concentrations of trace element were 
recorded in crystalline weathered of granites, metamorphic sandstone, sand deposits, and morainic sandy loams. There is a tendency for scarce selenium provinces to be confined to areas where acidic igneous rocks exit (Bilec'ka \& Onul, 2013).

Soils inherit the level of selenium concentration of parent rocks. Selenium in soils and rocks, which is present in various compounds that pass into water extracts and it is displaced from the solid phases by saline solutions (exchange cations), which are contained by an acetate-ammonium buffer solution. Selenium distribution in soils is influenced by their grain-size distribution, humus content, carbonates and physical clay (Neal, 1995). Selenium content in different soils usually varies from 0.1 to $2 \mathrm{mg} / \mathrm{kg}$ with slight deviations from this indicator (Gupta \& Gupta, 2000; Surai, 2007). Tropical and subtropical soils contain relatively high levels of selenium (>0.30 mg/kg). Soils in temperate and desert climates have average selenium concentrations of (0.14-0.30 mg/kg), while soils in temperate and humid climates are selenium deficient of $(<0.12 \mathrm{mg} / \mathrm{kg})(\mathrm{Tan}$ et. al., 2002$)$.

It is established that scarce selenium is characteristic mainly for acid soils and excess for alkaline ones. In soils with a pH of 45 , a significant amount of trace element is found in the form of elemental selenium and a small amount of selenite ions. The latter are formed in an alkaline environment. They are quite stable and can migrate until they are adsorbed by mineral or organic particles. That is why, selenium content in alkaline soils is increased. The average selenium content in surface layer of the Earth's soil is $0.4 \mathrm{mg} / \mathrm{kg}$. In some regions, its amount varies from 0.01 to $300 \mathrm{mg} / \mathrm{kg}$. Consequently, there are areas (selenium scarce and selenium toxic province) with a normal amount of trace element. Based on the total selenium content, the following limits are proposed for areas of different soil availability of this trace element, $\mu \mathrm{g} / \mathrm{kg}$ : less than 125 is area of selenium scarce; 125-175 are marginal scarce; 175-3000 are optimum area; more than 3000 are excess area (Ibatullin et. al., 2004; KabataPendias \& Mukherjee, 2007).

Selenium-toxic soils are found mainly in countries with arid climates but they occupy small areas. Increased selenium concentrations in soils are typical for areas where parent rocks and ores with a high selenium content are distributed. Such soils are found in Ireland (counties: Limerick, Tipperary, Meath), Canada (States: Alberta, Saskatchewan, Minnesota), Colombia, USA (States: North and South Dakota), China (Enshi province) in the southern Urals, Chelyabinsk and Tuva regions of Russia. However, the soils of many countries are marked by selenium scarce (Temmerman et al., 2014; Zhang et al., 2014). Geochemical provinces with selenium scarce are found in New Zealand, Australia, China, the USA, Finland, Denmark, Atlantic Canada,the CIS countries, etc. (Ermakov, 2004; Li et al., 2007; Fordyce, 2013). The most frequent selenium-deficient areas occurred in a large area of non-Chernozem zone which stretches from the North-East borders of the United States, across Europe (North Germany, Holland, Poland, through Baltic countries, Central Russia) to Ural mountains, then across Siberia to the Eastern Russia borders(Ermakov, 2006).

In the former USSR territory, the range of selenium content in soils is determined in the limit from 0.01 to $0.50 \mathrm{mg} / \mathrm{kg}$ (Ibatullin et. al., 2004; Kiriljuk, 2006), in polluted soils it can reach of $1.2 \mathrm{mg} / \mathrm{kg}$ or higher (Golubkina et. al., 2002).

To date, no large-scale mapping of selenium content has been carried out in the soils of certain region and province. There are only some reports that selenium concentratio in soils of, for example, the Moscow region is $0.25-0.72 \mathrm{mg} / \mathrm{kg}$, Bryansk is $0.23-$ 0.69; Norilsk is 0.86; Irkutsk is 0.04-0.18; Chita is 0.19-0.21; Kemerovo is 0.26-0.42; Amur is 0.04-0.12; Tuva is 0.78-1.10; Latvia is 0.50-1.01; the Republic of Belarus is 0.03-0.42; the Republic of Moldova is 0.18-0.35 mg/kg (Golubkina \& Papazjan, 2006; Mojseenok et. al., 2006; Perepjolkina, 2007; Kapital'chuk et. al., 2011).

The number of scientific papers of selenium content in the soils of Ukraine is also limited. Thus, its concentration in upper (0$20 \mathrm{~cm}$ ) soil horizon of Chernivtsi region is $0.19-0.60 \mathrm{mg} / \mathrm{kg}$ (Rudenko \& Dmytruk, 1999), Odessa is 0.17-0.69 mg/kg (Shhelkunov et. al., 2001), South Prysyvaska aggradation plain is $0.19-1.34 \mathrm{mg} / \mathrm{kg}$ (Popenko et. al., 2012). There is data that selenium content in the soils of Ukraine natural lands on average is $0.10 \mathrm{mg} / \mathrm{kg}$. The lowest selenium content was found in samples taken in Khmelnytskyi region it was $0.014 \mathrm{mg} / \mathrm{kg}$. Selenium content in the soils of agricultural lands in the territories of Zaporizhia (0.204 $\mathrm{mg} / \mathrm{kg})$, Dnepropetrovsk (0.166 mg/kg), Zakarpattia $(0.152 \mathrm{mg} / \mathrm{kg})$, Zhytomyr $(0.130 \mathrm{mg} / \mathrm{kg})$, Sumy (0.130 mg/kg) and Mykolaiv $(0.120 \mathrm{mg} / \mathrm{kg})$ regions was quite high. In general, according to the research results, soils in Ukraine are characterized by a reduced selenium content with a local increase in its concentration in certain regions. This indicator increases in the direction of forest-steppe-foothill-mountain zones. These features are related to the chemical composition of parent rocks and direction of soil formation processes (Suchkov\& Bardov, 1999).

\section{Selenium in natural waters}

Another criterion of biogeochemical forecast of selenium status of territories is selenium content in surface and ground waters. Selenium is much less in water than in soils. Thus, seawater contains $0.11-0.20 \mu \mathrm{g} / \mathrm{l}$ of selenium (Plant et. al., 2003). Selenium concentration in rivers slightly prevails over its concentration in seawater. Selenium monitoring in natural waters in certain regions of the former USSR countries showed that almost all investigated water samples its concentration was low, except of waters polluted territories and waters of hydrogeochemical provinces with a high content of element (Ural, Altai, Tuva, Kamchatka, Donetsk, Central Asian, Moldavia). In addition, the data obtained show that selenium concentration in surface and ground water is not the same. Thus, in river waters of the European Russia, selenium content ranges from 0.20-0.50 $\mu$ g/l; Belarus from 0.35-0.85; Central Asia from 0.30-2.00 (Reilly, 2006); Central Siberia is 0.11 (Golubkina et. al., 2004); Altai Mountains from 0.08-0.55 (Mal'gin et. al., 2000); Eastern Ukraine from 0.13-1.10 (Janchev \& Sulejmanov, 2004); Moldova from $1.00-8.80 \mu \mathrm{g} / \mathrm{l}$ (Kapital'chuk et. al., 2011). In ground water of these regions, selenium concentration was higher and amounted to $0,50-2,03 ; 0,40-0,85 ; 2,20-2,40 ; 0,09-3,50 ; 0,10-2,09 ; 0,10-2,30 ; 4,00-7,10 \mu \mathrm{g} / \mathrm{l}$, accordingly. The main sources of selenium entering in surface waters are precipitation, solid atmospheric constituents (release of volatile selenium-containing compounds into atmosphere from volcanic rocks) and soil selenium. Distribution of selenium in water depends on temperature, salt concentration, solubility, chemical structure and physical form, as well as physical parameters which are determined by movement of water masses and sediment.

In surface waters, under the influence of geogenic processes or anthropogenic emissions, selenium concentrations may periodically exceed of $100 \mu \mathrm{g} / \mathrm{l}$ but they are usually in range of 1-10 $\mu$ g/l (Ralston et. al., 2009). In regions with developed industry 
and infrastructure selenium concentration in water can significantly increase, in particular, in surface waters up to $400 \mu \mathrm{g} / \mathrm{l}$ (Nriagu, 1989) and wastewater up to 40-50 $\mu \mathrm{g} / \mathrm{l}$ (Jacobs, 1989).

Drinking water contains up to $10 \mu \mathrm{g} / \mathrm{l}$ of selenium, which corresponds to the maximum permissible concentration (Nordberg et. al., 2007). The maximum values of this indicator can be in range of 50-160 $\mu \mathrm{g} / \mathrm{l}$ (WHO, 2011). According to the research results by Ukrainian scientists was established that selenium content in drinking water in both industrial and agro-industrial cities does not differ significantly and ranges from 0.35 to $0.66 \mu \mathrm{g} / \mathrm{l}$ (Bilec'ka \& Zubyk 2007). Low selenium concentrations (0.02$0.69 \mu \mathrm{g} / \mathrm{l})$ are found in drinking water and in other countries of the world (Nriagu et. al., 2011).

The content of trace element in mineral waters on the territory of Ukraine (Carpathians) ranges from 1.2-54.5 $\mu \mathrm{g} / \mathrm{l}$. The highest selenium concentration is typical for mineral waters of bicarbonate type (up to $40.8 \mu \mathrm{g} / \mathrm{l}$ ). However, selenium is also found in other types of mineral waters: sulfate, chloride, bicarbonate-chloride and bicarbonate-sulfate. Scientists associate formation of mineral composition of these waters with ancient volcanogenic crystalline rocks of the Carpathians folded zone and marine sediments deposits of the Carpathian and Zakarpattia lowlands, which contain a significant amount of organic matter of petroleum origin (Suchkov \& Bardov 1999). It should be noted that depending on the oxidation-reduction conditions (value of Eh potential), selenium in natural waters can exist in different migration forms. In selenium-containing ground mineral waters with a high Eh value (more than $200 \mathrm{mV}$ ), selenium migrates as $\mathrm{SeO}_{3}{ }^{2-}$ anions, with a low Eh value (less than $100 \mathrm{mV}$ ) as $\mathrm{HSe}$ ions. Selenium concentration in ground mineral waters may depend not only on the value of Eh potential but also on the selenium reduction process (Shestopalov et. al., 2011). For comparison, in the natural mineral waters of Caucasus region ("Yessentuki", “Nagutskaya”, “Novoterskaya healing”), the average selenium content is 23-48 $\mu$ g/l (Shljapunova \& Sergeev, 2010).

\section{Selenium in plants and grain feeds}

The variability of biochemical soil properties and water in different regions of the world causes significant differences of selenium content in plants. The total selenium contentin in plants depends on a number of factors: soil type, pH value, redox potential, selenium reserves in soils, forms of selenium compounds (available or unavailable), precipitation, temperature and growth stage of plant (Galeas et. al., 2007; Popenko, 2015). Acidic soils are dominated by selenides and selenium sulfides, which are sedentary and therefore hard-to-reach for plants. Soils whose $\mathrm{pH}$ is close to neutral are dominated exclusively by selenites, which are actively fixed by hydroxides and iron oxides and are therefore also difficult to access for plants. Alkaline soils contain selenates that are easily soluble and sufficiently mobile, which makes them available to plants. In addition, selenium uptake by plants can be hindered by the presence of interfering substances in soils, such as sulfur (Kabata-Pendias \& Mukherjee, 2007). In plants, the following basic selenium compounds have been identified as selenate,Y-glutamyl-Se-methylselenocysteine, selenocystine, selenohomocysteine, selenocistationin, Se-methylselenocysteine, Se-methylselenomethionine, selenomethionine,dimethylsulfoniopropionate and dimethyldiselenide (Hasanuzzaman et. al., 2010; Gupta \& Gupta, 2017). At the same time, it was found that the level of selenocystin, methylselenocystein and Y-glutamyl-Se-methylselenocystein in plants is relatively low and does not depend on selenium content in soil (Tapiero et. al., 2003).

In the terrestrial parts of plants selenium concentration is higher than in root, but lower than in the seeds. However, in some cases, plant stems and leaves accumulate selenium much more than grains (Kapital'chuk \& Golubkina, 2008). Selenium is transported inside the plant through sulfate transporters present in root plasma membrane (Li et al., 2008).After entering to the plant, it moves to leaves and is metabolized in plastids to SeCys or SeMet. Depending on the plant species and environmental conditions, SeCys can be converted to elemental Se in presence of SeCys lyase enzyme, or it can be methylated to Me-SeCys by selenocysteine methyltransferase, or it can be converted to selenomethionin (SeMet) by a series of enzymes (Pilon-Smits \& Quinn, 2010).

According to the ability to accumulate selenium, plants are divided into three groups:

- accumulators plants-can accumulate selenium up to $1000 \mathrm{mg} / \mathrm{kg}$ of dry matter or more (some species of Astragalus, Brassica, Xylarrhiza, Oonopsis, Stagley, etc.);

- plants that can accumulate selenium up to $200 \mathrm{mg} / \mathrm{kg}$ of dry matter (some species Aster, Grindelia, Gutierrezia, Atriplex, Penstemon, Castillejia);

- non-accumulating plants are able to accumulate selenium on average $0.1-1.0 \mathrm{mg} / \mathrm{kg}$ of dry matter (most crops) (Golubkina \& Papazjan, 2006).

Usually, selenium content in forage plants varies from 0.1 to $2.0 \mathrm{mg} / \mathrm{kg}$ of dry matter. On average, plant feeds contain of $0.04-$ $0.08 \mathrm{mg} / \mathrm{kg}$ selenium of dry matter.

As a result of conducted research, it is established that the minimum selenium content in traditional animal husbandry and poultry farming the grain feeds is $0.001 \mathrm{mg} / \mathrm{kg}$ (in Chita region of Russia), and the maximum is $2.00 \mathrm{mg} / \mathrm{kg}$ (in South Dakota) (Golubkina \& Papazjan, 2006). Monitoring of selenium content in grain feeds of different Russian regions revealed the existence of wide limits of trace element concentration, in particular: in wheat are 0.001-0.271 mg/kg, barley are 0.003-0.200, corn are $0.036-0.242$, peas are $0.046-0.198 \mathrm{mg} / \mathrm{kg}$. At the same time, the average amount of selenium accumulation by grain group in seven Russian Federal Districts ranged from 0.076 to 0.126 mg/kg (Golubkina \& Papazjan, 2006; Papazjan \& Golubkina, 2006; Papazjan \& Golubkina, 2008). The most selenium scarce of Russian provinces were Chita region, Buryatia and Khabarovsk Krai. Research conducted by Institute of Ecology and Geography of the Academy of Sciences of Moldova has shown that selenium content in grain feeds of this country is also low. Thus, its level in wheat ranges from 0.078 to $0.143 \mathrm{mg} / \mathrm{kg}$; barley from 0.094 to 0.157 ; corn from 0.089 to $0.128 \mathrm{mg} / \mathrm{kg}$. On average, the amount of selenium removal from soil with grain of these crops are $0.111,0.125$ and $0.104 \mathrm{mg} / \mathrm{kg}$, respectively (Kapital'chuk \& Golubkina, 2008). The Baltic countries are characterized by a higher selenium concentration (on average $0.2 \mathrm{mg} / \mathrm{kg}$ ) in cereals (Golubkina, 1998).

Selenium level is quite low in feed ingredients produced in Ukraine usually less than 0.1 parts per million (Melnichuk \& Surai, 2008). Domestic scientists have analyzed a large number of plant samples came to conclusion that feed concentrated from grain crops grown in Ukraine are scarce in selenium. In the main grain feeds of steppe and forest-steppe zones and Polissya 
zone, it is on average contained, respectively, $\mathrm{mg} / \mathrm{kg}$ : in corn are 0.058 and 0.059 ; wheat are 0.038 and $0.045 ;$ barley are 0.089 and 0.074; oats are 0.072 and 0.074 (Djachenko \& Sivik, 2008). Similar data on low selenium concentrations in concentrated feed are found in publications by other Ukrainian scientists (Sobolev, 2009). It is significant that for most European countries,selenium content in feed grains does not exceed of $0.05 \mathrm{mg} / \mathrm{kg}$, which indicates a deep scarce of this element for farm animals and poultry (Surai, 2006).

It was found that selenium concentration in feed is unstable. Along with the soil composition and acidity, it can be influenced by factors such as a period of the year, crop varieties, the development phase, agricultural cultivation techniques, type of harvest, storage conditions, protein and heavy metal content, microbial activity, etc. (Zhao et. al., 2005; Mehdi et. al., 2013).

\section{Selenium in poultry breeding products}

On the one hand, there is a certain correlation between selenium content in soil and in forage plants and on the other hand the poultry organism (Surai, 2002; Petrovic et. al., 2006; Tishenkov et. al., 2006; Ivahnik, 2008;). In the absence of seleniumcontaining premixes, selenium concentration in poultry body can range from 0.02-0.06 $\mathrm{mg} / \mathrm{kg}$ (in scarce selenium areas, in China) to 0.4 and $0.7 \mathrm{mg} / \mathrm{kg}$ (in selenosis areas, in South Dakota and Venezuela, respectively).

Accumulation of selenium in poultry's body has its own specificity, it can be deposited in the cells of all tissues except adipose tissue. Organs and tissues by their ability to accumulate selenium can be listed in descending order: liver - kidneys - lungs muscles - bones - heart (Combs, 2001; Surai, 2006). However, some scientists claim that poultry muscles accumulate less selenium than bones, particularly tibia (Ivahnik, 2008) and heart (Gonockij et. al., 2002). In addition,selenium deposition was found to be less pronounced in pectoral muscles of most bird species than in leg muscles (Kricova et. al., 2003; Sobolev et. al., 2017).

Today, poultry can be provided with selenium only by adding inorganic or organic forms of this trace element. And in the future, it is unlikely to be possible, by changing the type of plant nutrition, to increase the content of this trace element in the main grain components of compound feeds to such a level as to meet the need for highly productive poultry in selenium. Selenium levels increasing in poultry diet, its concentration in poultry products, in particular meat and eggs increases (Fisinin et. al., 2009; Bennett \& Cheng, 2010; Chantiratikul et. al., 2020). However, data on effect of selenium additives in mixed feed on its accumulation in the organs and tissues of various poultry species are quite contradictory and do not always lend themselves to correct comparison.

In experiments on laying hens, it was found that at a low selenium level in diet $(0.03 \mathrm{mg} / \mathrm{kg})$, its content in the chest muscles were $5.3 \mu \mathrm{g} / \%$. It has been experimentally proved that feeding mixed feeds with selenium additives of 0.2 and $0.6 \mathrm{mg} / \mathrm{kg}$ to laying hens for six months resulted in varying degrees of trace element accumulation in the pectoral muscles of 18.6 and 41.0 $\mu g / \%$, respectively (Ivahnik, 2008). Another scientist (Shevchenko, 2006) obtained results which prove that when consuming selenium-enriched compound feeds at a dose of $0.2 \mathrm{mg} / \mathrm{kg}$ for six weeks, selenium content in laying hens muscle tissue was only $5 \mu \mathrm{g} / \%$, and at a dose of $0.5 \mathrm{mg} / \mathrm{kg}-13.0 \mu \mathrm{g} / \%$.

Due to the natural selenium content in compound feeds $(0.09-0.18 \mathrm{mg} / \mathrm{kg})$ in the muscles of 60 -day-old broiler poultry of "Smena" cross, its level was 16.9 g/\% (Japparov \& Rodionova, 2006). The concentration of element was 6.0 and 7, kg/\% in chest and leg muscles of cross "Cobb" broiler poultry were raised on a selenium-deficient diet (0.08-0.10 mg/kg). The introduction of selenium supplements in mixed feed at doses of $0.2-0.4 \mathrm{mg} / \mathrm{kg}$ increased its concentration in the chest muscles of their peers to $7.3-12.4 \mu \mathrm{g} / \%$, and in the leg muscles to $8.7-14.3 \mu \mathrm{g} / \%$ (Sobolev et. al., 2019). Meat of 49-day-old broiler poultry were enriched with selenium at the rate of 0.2 and $0.3 \mathrm{mg} / \mathrm{kg}$ during growing period, its contained an average of 5.6 and $8.2 \mu \mathrm{m} / \%$, respectively (Rassolov et. al., 2008). Similar data on selenium concentration in muscle tissue $(8.2 \mu \mathrm{g} / \%)$ were obtained by studies on Hubbard Flex cross broiler poultry, but when it was introduced into feed at a dose of $0.5 \mathrm{mg} / \mathrm{kg}$ (Ponomarenko, 2007).

Even at the same doses of its introduction into feed differences in selenium concentration in meat of laying hens and broiler poultry are due to the difference in geochemical zones and feeding conditions, in which studies were conducted, diet composition and different availability of trace elements from various chemical compounds. Analysis of available literature sources shows that published data on selenium accumulation in muscle tissue of waterfowl is too small. There is a report that when feeding of mixed feeds enriched with selenium at a dose of $0.3 \mathrm{mg} / \mathrm{kg}$ to ducklings during growing period, its content in the chest muscles increased to $9.4 \mu \mathrm{g} / \%$, against of $3.4 \mu \mathrm{g} / \%$ in control group (Kravchenko, \& Djachenko, 2013). In another work (Sobolev, \& Povoznikov, 2015), the authors claim that when selenium was introduced into compound feed for ducklings at a dose of $0.4 \mathrm{mg} / \mathrm{kg}$, its concentration in the pectoral muscles were $9.0 \mu \mathrm{g} / \%$, and in the femoral muscles were $12.8 \mu \mathrm{g} / \%$. At the same time, in ducklings which are raised on a selenium-deficient diet, selenium content was 5.6 and $7.3 \mu \mathrm{g} / \%$ in the chest and leg muscles, respectively.

In studies on 75-day-old goslings, it was found that in youngster chest muscles which did not receive selenium supplements it contained of $13.1 \mu \mathrm{g} / \%$, and the leg muscles of $11.5 \mu \mathrm{g} / \%$. Trace element concentration in goslings muscles that received an additional of 0.4 and $0.5 \mathrm{mg} / \mathrm{kg}$ increased and amounted to 17.7 and $18.2 \mu \mathrm{g} / \%$ in the chest muscles, $18.1 \mathrm{and} 18.4 \mu \mathrm{g} / \%$ in the femoral muscles, respectively.(Sobolev, 2013).

In the absence of selenium additives in feed, trace elements accumulation in egg of different bird species can vary from $2 \mu \mathrm{g}$ (in quail) to $580 \mu \mathrm{g}$ (in ostrich) (Golubkina \& Papazjan, 2006). In a normal poultry egg, selenium concentration ranges from 0.057 $\mathrm{mg} / \mathrm{kg}$ (Paton et. al., 2002) to $0.268 \mathrm{mg} / \mathrm{kg}$ (Liu et. al., 2020). In addition, it was found that selenium content in eggs does not change with bird age (Fisinin et. al., 2009). A general feature for all bird species is that selenium content in egg components decreases in the following order: yolk > protein > shell > inner shell membrane (Surai \& Dvorskaja, 2003).

The introduction of selenium-containing drugs in poultry diets increases selenium concentration in all egg components (yolk and protein), but drugs effectiveness is different (Skřivan et. al., 2010). According to the ability to increase selenium concentration in a poultry egg, selenium-containing preparations can be arranged in the following order: selenium yeast > nano-selenium > sodium selenite (Meng et. al., 2019). 
The ability of poultry to create selenium reserves in tissues and organs is limited. If physiologically necessary reserves exceed norm, the excess of incoming selenium is eliminated in a short time (Suchy et. al., 2014). Thus, the amount of selenium deposition in poultry meat and eggs depends on its content in diet, drug form and the duration of introduction into feed. In addition, a significant role in selenium accumulation is played by poultry species and breed characteristics which are probably due to genetic and physiological factors.

The above data on selenium accumulation in the organs and tissues of various poultry species suggest that selenium can also affect humans being in trophic chain: feed - poultry - products. Selenium, which mainly enters to the human body with food and water, performs unique multiple functions: catalytic, structural, regulatory in process of which it interacts with enzymes, proteins, vitamins, trace elements and biological membranes. Selenium participate in redox reactions involved in immunogenesis, spermatogenesis and hormonopoiesis, plays a role in the transmission of visual images to retina. According to the results of numerous scientific studies are established that selenium has antioxidant, anti-carcinogenic, radioprotective, immune-stimulating , anti-virus and antitoxic properties. There is direct evidence of the influence of selenium on osteogenesis, reproductive function, growth and development processes (Sobolev et. al., 2018). The biochemical functions of selenium are determined not by trace element itself, but by selenoproteins which contain a selenocysteine residue as an integral part of their active center. To date, more than 30 such specific selenoproteins have been isolated and identified in their pure form, but biological role is known only 15, among them, four types of glutathione peroxidase: classical cytosol (GSH-Px1), gastrointestinal (GSH-Px2), plasma (GSH-Px3) and phospholipid hydroperoxide (GSHPx4); thioredoxin reductase (TrxR) which has different isoforms: cytoplasmic and two mitochondria; selenoprotein P (SelP); selenoprotein W (SelW); selenoprotein - methionine sulfoxide reductase $B\left(M S R_{B}\right)$; 5-iodothyronine deiodinase (ID) which has three types - I, II and III (Rocha et. al., 2017).

Today, most of the world's population (except in some regions) consumes less selenium than necessary. Insufficient intake of selenium in the human body (less than 15-30 $\mu \mathrm{g} /$ day) leads to development one of the hypomicroelementosis - hyposelenosis. About 75 different diseases and pain symptoms are associated with selenium scarce (Rayman, 2012; Rakov \& Muz', 2019). Selenium scarce is considered as a possible etiological factor of 14 cardiovascular diseases, including distal cardiomyopathy (Keshan's disease), atherosclerosis, coronary heart disease, myocardial infarction, arterial hypertension, etc. (Benstoem et. al., 2015). Some scientists associate Kashin-Bek's disease (KBD) with a deep selenium scarce in soils, plants and food. This is a severe osteo-articular disease (mainly affecting children), common in the South-Eastern districts of the Chita region, North Korea, and North-Eastern China (Yao et. al., 2011; Ermakov et. al., 2020).

An inverse relationship have been established between the frequency of human cancer and selenium content in food, in the body and environment. In regions with a low selenium content, the risk of malignant neoplasms of the lungs, stomach, large intestine, rectum, pancreas, liver, glandula mammaria and prostate is significantly higher (Zachara et. al., 2005; Roman et. al., 2014; Cai et. al., 2016). Clinical and experimental studies have shown that in pathogenesis of diseases such as cataracts and pancreatic cystic fibrosis is a scarce of a number of elements including selenium (Kumara \& Priyadarsinib, 2014).

It is not possible to say that selenium scarce is cause of chronic hepatitis or rheumatoid arthritis, but the severity of these diseases depends on element concentration in the body (Knyazeva et. al., 2016; Yu et. al., 2016; Galal et. al., 2017).

Great importance is attached to body's selenium provision in prevention of neurodegenerative diseases (Alzheimer's disease, Parkinson's disease) (Ellwanger et. al., 2016; Solovyev et. al., 2018).

Reproductive function is disrupted in people with low selenium status which can lead to infertility and impotence and life expectancy is shortened due to premature aging (Ray et. al., 2006; Qazi et. al., 2018; Qazi et. al., 2019). Today, it has already been proven that "sudden" infant mortality syndrome is based on selenium and vitamin E scarce (Reid, 2007). Remarkably, there is a fact that the symptoms of diseases caused by insufficient intake of selenium in the human body are quite diverse and the list of diseases is still far from complete.

Analysis of the actual selenium consumption by population with crop and animal products indicates an insufficient (or even low) level of the body's provision of this microelement. The average daily selenium consumption by human varies greatly: from $10 \mu \mathrm{g}$ in selenium-deficient regions to $1400 \mu \mathrm{g}$ in selenosis regions. A significant number of countries in the world are characterized by moderate and low rates of selenium consumption, and high values of this indicator (from $200 \mu \mathrm{g} / \mathrm{day}$ and above) only installed in countries such as Canada, Japan, the Philippines, Thailand and Venezuela (Mishanin, 2008). In many countries of the world, the level of selenium consumption with food remains low, $\mu$ g/day: New Guinea is 20; Nepal is 23; India is 27; Egypt is 29; Belgium, Serbia, Slovenia are 30; Turkey is 32; England, Spain, Slovakia are 35; Sweden, France, Portugal are 38; Germany, Italy are 43; Austria is 48. Research shows that selenium consumption decreases every year (Surai, 2006).

The daily human selenium consumption is 50-200 $\mu \mathrm{g}$ recommended by FAO/WHO experts and is assessed as sufficient and safe. According to one estimate, the minimum human need of selenium is $16 \mu \mathrm{g} / \mathrm{day}$ for women and for men are $21 \mu \mathrm{g} / \mathrm{day}$ (WHO/FAO/IAEA, 1996), for others are $40 \mu \mathrm{g} /$ day. (Whanger, 1998). The upper permissible (safe) level of selenium consumption reaches of $400 \mu \mathrm{g} /$ day (Kipp et. al., 2015). The world's maximum allowable daily intake of trace elements is $800 \mu \mathrm{g}$ (FairweatherTait et. al., 2011).

A number of countries have developed recommended selenium intake standards, namely ( $\mu$ g/day): Finland - 120 (adults) (Alfthan \& Aro, 2005); Australia - 85 (men) and 70 (women) (Tinggi, 2003); Great Britain - 75 (men) and 60 (women) (Thomson, 2004); ); New Zealand - 70 (men) and 60 (women) (NRVs, 2006); Germany, Austria, Switzerland - 70 (men) and 60 (women); Nordic countries - 30-60 (adults) (Kipp et. al., 2015 Canada, USA, Europe - 55 (adults) (Thomson, 2004); Russia - 63 (Adults) (Tutel'jan, 2009); Belarus - 70 (adults) (Zajcev et. al., 2005); Ukraine - 70 (adults) (Normy, 2017). Extrapolation of these values taking into account the body weight of children and adolescents allows us to calculate their physiological need for selenium. There are several ways to correct the selenium status of human population: selenium consumption in form of pharmaceutical forms or dietary supplements, production of selenium-enriched bread, cultivation greens and vegetables of selenium enriched (dill, radishes, garlic, etc.),selenium enrichment of beverage, selenium addition to table salt, production of selenium enriched 
animal products (Haug et. al., 2007). The most safe and effective way to maintain the necessary level of selenium for the human body can be achieved only through poultry and livestock products by mandatory introduction of premixes containing highly effective biologically available forms of selenium into feed. This will ensure a relatively high level of trace element in meat and dietary products (eggs and milk) and would eliminate cases of toxicosis in human population due to buffer effect of animal tissues. At the same time, this approach will contribute to improving productive qualities of farm animals and poultry (Mehdi \& Dufrasne 2016; Surai, 2018).

\section{Conclusions}

Summarizing published data, we found that in Ukraine has not yet been carried out a comprehensive ecological and toxicological analysis on selenium migration in environment and food chains. The current research results are isolated, incomplete and require the systematization and clarification.

As follows from the above, Ukrainian territory can be attributed to scarce selenium biogeochemical provinces according to detected selenium concentrations in natural waters and soils. Ukrainian scientists have been monitoring the selenium content in the feed, especially the domestic animals concentrated feed and revealed low concentrations of this element, which confirms the need to include the selenium in poultry feed. Also even insufficient number of publications dedicated to correction of selenium status, testified that its should be enriched among Ukrainian livestock and poultry products.

\section{References}

Alfthan, G., \& Aro, A. (2005). Environmental effects of selenium fertilization - Is there a potential risk? Proc. Int. Conf. "Twenty years of selenium fertilization is here a potencial risk?" September 8-9, 2005. Helsinki, 33-35.

Arnér, E.S.J. (2011). History of selenium research. In: Hatfield, D., Berry, M., \& Gladyshev, V. (eds). Selenium : its molecular biology and role in human health, 1-19. Springer, New York, NY. doi:10.1007/978-1-4614-1025-6_1

Bennett, D.C., \& Cheng, K.M. (2010). Selenium enrichment of table eggs. Poultry Science, 89(10), 2166-2172. doi:10.3382/ps.2009-00571

Benstoem, C., Goetzenich, A., Kraemer, S., Borosch, S., Manzanares, W., Hardy, G., Stoppe, C. (2015). Selenium and its supplementation in cardiovascular disease - what do we know? Nutrients, 7(5), 3094-3118. doi:10.3390/nu7053094

Bilec'ka, E.M., \& Onul, N.M. (2013). Selen u dovkilli: ekologo-gigijenichni aspekty problemy : monografija. Akcent, Dnipropetrovs'k (in Ukrainian).

Bilec'ka, E.M., \& Zubyk, N.M. (2007). Gigijenichna ocinka vmistu mikroelementa selenu u vodi Dnipropetrovs'koi' oblasti. Dovkillja ta zdorov'ja, 1, 56-60 (in Ukrainian).

Boyd, R. (2011). Selenium stories. Nature Chemistry, 3, 570. doi:10.1038/nchem.1076

Brygadyrenko, V.V., Lieshchova, M.A., Bilan, M.V., Tishkina, N.M., \& Horchanok, A.V. (2019). Effect of alcohol tincture of Aralia elata on the organism of rats and their gut microbiota against the background of excessive fat diet. Regulatory Mechanisms in Biosystems, 10(4), 497-506. doi:10.15421/021973

Cai, X., Wang, C., Yu, W., Fan, W., Wang, S., Shen, N., Wu, P., Li, X., \& Wang, F. (2016). Selenium Exposure and Cancer Risk: an Updated Meta-analysis and Meta-regression. Scientific Reports, 6, 19213. doi:10.1038/srep19213

Calabrese, S. (2009). Atmospheric deposition of volcanogenic major and trace elements on Mt. Etna (Sicily). European Journal of Mineralogy.

Chantiratikul, A., Arunsangseesod, O., Wangkahart, E., Leamsamrong, K., \& Chantiratikul, P. (2020). Effect of dietary selenium from selenium-enriched kale sprout, selenomethionine, and sodium selenite on performance and selenium concentrations in the tissues of growing quails. Asian-Australasian Journal of Animal Sciences. doi:10.5713/ajas.20.0111

Combs, G.F.Jr. (2001). Selenium in global food systems. British Journal of Nutrition, 85, 517-547. doi:10.1079/bjn2000280

Darmohray, L.M., Luchyn, I.S., Gutyj, B.V., Golovach, P.I., Zhelavskyi, M.M., Paskevych, G.A., \& Vishchur, V.Y. (2019). Trace elements transformation in young rabbit muscles. Ukrainian Journal of Ecology, 9(4), 616-621

Djachenko, L.S., \& Sivik, T.L. (2008). Selen u kormah Ukrai'ni. Segodnja dlja zavtra, 2, 20-22 (in Ukrainian).

Ellwanger, J.H., Franke, S.I., Bordin, D.L., Prá, D., \& Henriques, J.A. (2016). Biological functions of selenium and its potential influence on Parkinson's disease. An Acad Bras Cienc, 88(3 Suppl), 1655-1674. doi:10.1590/0001-3765201620150595

El-Ramady, H., Domokos-szabolcsy, E., \& Shalaby, T., Joe, P., \& Fári, M. (2015). Selenium in agriculture: water, air, soil, plants, food, animals and nanoselenium. In: Lichtfouse E., Schwarzbauer J., Robert D. (eds) CO2 Sequestration, Biofuels and Depollution. Environmental Chemistry for a Sustainable World, Springer, Cham vol 5, 153-232. doi:10.1007/978-3-31911906-9_5

Ermakov, V., Gulyaeva, U., Danilova, V., Safonov, V., Tyutikov, S., \& Degtyarev, A. (2020). Urov endemic disease: peculiarities of biogeochemical food chains. EGU General Assembly, 2020-2206, doi:10.5194/egusphere-egu2020-2206

Ermakov, V.V. (1995). Biogeohimicheskie provincii: koncepcija, klassifikacija i jekologicheskaja ocenka. Osnovnye napravlenija geohimii, 183-196 (in Russian).

Ermakov, V.V. (2004). Biogeohimija selena i ego znachenie v profilaktike jendemicheskih zabolevanij cheloveka. Vestnik otdelenija nauk o zemle RAN, 1, 1-17 (in Russian).

Ermakov, V.V. (2006). Puti preodolenija nedostatochnosti selena. Selekor. Biologicheskoe dejstvie, 198-203 (in Russian).

Fairweather-Tait, S.J., Bao, Y., Broadley, M.R., Collings, R., Ford, D., Hesketh, J.E., \& Hurst, R. (2011). Selenium in human health and disease. Antioxid Redox Signal, 14(7), 1337-1383. doi:10.1089 / apc.2010.3275

Fisinin, V.I., Papazyan, T.T., \& Surai, P.F. (2009). Producing selenium-enriched eggs and meat to improve the selenium status of the general population. Crit Rev Biotechnol, 29(1), 18-28. doi:10.1080 / 07388550802658030 
Fordyce, F.M. (2013). Selenium Deficiency and Toxicity in the Environment. In: Selinus O. (eds) Essentials of Medical Geology. Springer, Dordrecht. doi:10.1007/978-94-007-4375-5_16

Galal, G., Ahmad, N., Mohammad, A., \& Bakrey, R. (2017). Serum selenium level in patients with chronic liver disease. Sohag Medical Journal, 21(1), 125-133. doi:10.21608/smj.2017.40037

Galeas, M.L., Zhang, L.H., Freeman, J.L., Wegner, M., \& Pilon-Smits, E.A.H. (2007). Seasonal fluctuations of selenium and sulfur accumulations in selenium hyperaccumulators and related nonaccumulators. New Phytologist, 173(3), 517-525. doi:10.1111 / j.1469-8137.2006.01943.x

Glinka, N.L., \& Ermakov, A.I. (2009). Obshhaja himija. Integral-Press, Moskva (in Russian)

Golubkina, N.A. (1998). Vlijanie geohimicheskogo faktora na nakoplenie selena zernovymi kul'turami i sel'skohozjajstvennymi zhivotnymi v uslovijah Rossii, stran SNG i Baltii. Problemy regional'noj jekologii, 4, 53-59 (in Russian).

Golubkina, N.A., \& Papazjan, T.T. (2006). Selen v pitanii: rastenija, zhivotnye, chelovek. Pechatnyj gorod, Moskva (in Russian).

Golubkina, N.A., Korchina, T.Ja., Merkulova, N.N., \& Pesin, S.A. (2004). Obespechennost' selenom zhitelej g. Surguta Tjumenskoj oblasti. Jekologicheskie sistemy i pribory, 3, 48-57 (in Russian).

Golubkina, N.A., Skal'nyj, A.V., Sokolov, Ja.A., \& Shhelkunov, L.F. (2002). Selen v medicine i jekologii. KMK, Moskva (in Russian).

Gonockij, V.A., Fedina, L.P., Dubrovskaja, V I., Gonockaja, V. A., \& Golubkina, N.A. (2002). Produkty profilakticheskogo naznachenija s povyshennym soderzhaniem selena. Ptica i ejo pererabotka, 2, 28-31 (in Russian).

Grinvud, N., \& Jernsho, A. (2008). Himija jelementov. BINOM, Laboratorija znanij, Moskva (in Russian).

Gromova, O.A., \& Gogoleva, I.V. (2007). Selen - vpechatljajushhie itogi i perspektivy primenenija. Trudnyj pacient, 5(14), 25-30 (in Russian)

Gross, J.L., Claes, J., Kathawa, J., \& Thoennessen, M. (2012). Discovery of zinc, selenium, bromine, and neodymium isotopes. Atomic Data and Nuclear Data Tables, 98(2), 75-94. doi:10.1016/j.adt.2011.12.001

Gupta, M., \& Gupta, S. (2017). An overview of selenium uptake, metabolism, and toxicity in plants. Frontiers in plant science, 7 , 2074. doi:10.3389/fpls.2016.02074

Gupta, U.C., \& Gupta, S.C. (2000). Selenium in soils and crops, its deficiencies in livestock and humans: Implications for management. Communications in soil science and plant analysis, 31(11-14), 1791-1807. doi:10.1080 / 00103620009370538

Hamidatou, L., Slamene, H., Akhal, T., \& Zouranen, B. (2013) Concepts, instrumentation and techniques of neutron activation analysis. In: Imaging and Radioanalytical Techniques in Interdisciplinary Research-Fundamentals and Cutting Edge Applications. In Tech, Rijeka, Croatia, 141-178. doi:10.5772 / 53686

Hasanuzzaman, M., Hossain, M.A., \& Fujita, M. (2010). Selenium in higher plants: physiological role, antioxidant metabolism and abiotic stress tolerance. Journal of Plant Sciences, 5(4), 354-375. doi:10.3923 / jps.2010.354.375

Haug, A., Graham, R.D., Christophersen, O.A., \& Lyons, G.H. (2007). How to use the world's scarce selenium resources efficiently to increase the selenium concentration in food. Microbial ecology in health and disease, 19(4), 209-228. doi:10.1080/08910600701698986

Ibatullin, I.I., Veshyc'kyj, V.A., \& Otchenashko, V.V. (2004). Vykorystannja selenu v roslynnyctvi ta tvarynnyctvi. Feniks, Kyi'v (in Ukrainian).

Ivahnik, G.V. (2008). Selen i vitamin E v kombikormah dlja jaichnyh kur. Efektyvni kormy ta godivlja, 2, 20-24 (in Russian).

Jacobs, L.W. (1989). Selenium in agriculture and the environment. Soil Science Society of America Special Publication, Madison, WI. doi:10.2136 / sssaspecpub23

Janchev, V.K., \& Sulejmanov, S.P. (2004). Monitoring selena v tehnogennyh i prirodnyh vodah v srede vokrug Luganskoj oblasti, Jekologija okruzhajushhej sredy stran SNG, 3, 84-88 (in Russian).

Japparov, I.A., \& Rodionova, T.N. (2006). Vlijanie selena na pokazateli selenovogo obmena u cypljat-brojlerov. Zootehnija, 9, 1819 (in Russian).

Kabata-Pendias, A., \& Mukherjee, A.B. (2007). Trace elements from soil to human. Springer-Verlag Berlin Heidelberg, New York. doi:10.1007/978-3-540-32714-1

Kapital'chuk, M.V., \& Golubkina, N.A. (2008). Bioakkumuljacija selena rastenijami na razlichnyh tipah pochv Moldovy. Agro HHI, 4-6, 81-83 (in Russian).

Kapital'chuk, M.V., Kapital'chuk, I.P., \& Golubkina, N.A. (2011). Akkumuljacija i migracija selena v komponentah biogeohimicheskoj cepi pochva - rastenija - chelovek v uslovijah Moldavii. Povolzhskij jekologicheskij zhurnal, 3, 323335 (in Russian).

Karnauhov, O.I., Mel'nychuk, D.O., Chebot'ko, K.O., \& Kopilevych, V.A. (2003). Zagal'na ta bioneorganichna himija. Nova Knyga, Vinnycja (in Ukrainian).

Kieliszek, M., \& Błażejak, S. (2016). Current knowledge on the importance of selenium in food for living organisms: a review. Molecules (Basel, Switzerland), 21(5), 609. doi:10.3390/molecules21050609

Kipp, A.P., Strohm, D., Brigelius-Flohé, R., Schomburg, L., Bechthold, A., Leschik-Bonnet, E., \& Heseker, H. (2015). Revised reference values for selenium intake. Journal of Trace Elements in Medicine and Biology, 32, 195-199. doi:10.1016/j.jtemb.2015.07.005

Kiriljuk, V.P. (2006). Mikrojelementy v komponentah biosfery Moldovy. Pontos, Kishinev (in Russian).

Knyazeva, A.K., Komarova, E.B., \& Kuvichko, N.N. (2016). Influence of selenium on clinical and laboratory parameters in patients with rheumatoid arthritis and subclinical hypothyroid dysfunction. Russian Open Medical Journal, 5, e0406.

Komlyk, V. O., \& Brygadyrenko, V. V. (2019). Morphological variability of Bembidion aspericolle (Coleoptera, Carabidae) populations in conditions of anthropogenic impact. Biosystems Diversity, 27(1), 21-25. http://doi.org/10.15421/011903 
Kovalchuk, I., Dvylyuk, I., Lecyk, Y., Dvylyuk, I., \& Gutyj, B. (2019). Physiological relationship between content of certain microelements in the tissues of different anatomic sections of the organism of honey bees exposed to citrates of argentum and cuprum. Regulatory Mechanisms in Biosystems, 10(2), 177-181. https://doi.org/10.15421/021926

Kravchenko, I.V., \& Djachenko, L.S. (2013). Jakist' produkcii' kachenjat za riznogo rivnja ta dzherel selenu v kombikormi. Suchasne ptahivnyctvo, 9(130), 13-15 (in Ukrainian).

Kricova, S., Boldizarova, K., Gresakova, L., Bobcek, R., Levkut, M., \& Leng, L. (2003). Chicken selenium status when fet a diet supplemented with Se-yeast. Acta Veterinaria Brno, 72, 339-346. doi:10.2754/avb200372030339

Li, H.F., McGrath, S.P., \& Zhao, F.J. (2008). Selenium uptake, translocation and speciation in wheat supplied with selenate or selenite. New Phytol,178, 92-102. doi:10.1111/j.1469-8137.2007.02343.x

Li, N., Gao, Z. D., Luo, D. G., Tang, X., Chen, D.F., \& Hu, Y.H. (2007). Selenium level in the environment and the population of Zhoukoudian area, Beijing, China. Science of the Total Environment, 381(1-3), 105-111. doi:10.1016/j.scitotenv.2007.03.027

Liu, H., Yu, Q., Fang, C., Chen, S., Tang, X., Ajuwon, K.M., \& Fang, R. (2020). Effect of selenium source and level on performance, egg quality, egg selenium content, and serum biochemical parameters in laying hens. Foods (Basel, Switzerland), 9(1), 68. doi:10.3390/foods9010068

Mal'gin, M.A., Puzanov, A.V., \&Majmanova, T.M. (2000). Selen v osnovnyh komponentah okruzhajushhej sredy Altaja. Himija v interesah ustojchivogo razvitija, 8(6), 837-843 (in Russian).

Martyshuk, T.V., Gutyj, B.V., Zhelavskyi, M.M., Midyk. S.V., Fedorchenko, A.M., Todoriuk, V.B., Nahirniak, T.B., Kisera, Ya.V., Sus, H.V., Chemerys, V.A. , Levkivska, N.D., \& Iglitskej, I.I. (2020). Effect of Butaselmevit-Plus on the immune system of piglets during and after weaning. Ukrainian Journal of Ecology, 10(2), 347-352. doi: 10.15421/2020_106

Mehdi, Y., \& Dufrasne, I. (2016). Selenium in cattle: a review. Molecules (Basel, Switzerland), $21(4)$, 545. doi:10.3390/molecules21040545

Mehdi, Y., Hornick, J.L., Istasse, L., \& Dufrasne, I. (2013). Selenium in the environment, metabolism and involvement in body functions. Molecules, 18(3), 3292-3311. doi:10.3390/molecules18033292

Melnichuk, S.D., \& Surai, P.F. (2008). Selenium status in Ukraine: food for thoughts. In: Surai, P.F., \& Taylor-Pickard, J.A. (eds), Current advances in selenium research and applications, 57-73. doi:10.3920/978-90-8686-642-7

Meng, T., Liu, Y., Xie, C., Zhang, B., Huang, Y., Zhang, Y., Yao, Y., Huang, R., \& Wu, X. (2019). Effects of different selenium sources on laying performance, egg selenium concentration, and antioxidant capacity in laying hens. Biological Trace Element Research, 189, 548-555. doi:10.1007/s12011-018-1490-z

Mishanin, Ju.F. (2008). Vzaimosvjaz' selena v biologicheskoj cepi: pochva - rastenie - zhivotnye - produkcija - chelovek. Perspektivnye biotehnologii pererabotki sel'skohozjajstvennogo syr'ja, 135-137 (in Russian).

Mojseenok A.G., Muroh V.Y., \& Tarasov Ju.A. (2006). Preduprezhdenye nedostatka selena v pytanyy (k programme sojuznogo gosudarstva Rossyja - Belarus'). Selekor. Byologycheskoe dejstvye, 24-35 (in Russian).

Neal, R.H. (1995). Selenium. In: Alloway, B.J., Ed., Heavy Metals in Soils. Blackie Academic and Professional, London, 260-283. doi:10.1007/978-94-011-1344-1_12

Nordberg, G.F., Fowler, B.A., Nordberg, M., \& Friberg, L. (2007). Handbook on the toxicology of metals, 3rd ed. Academic Press, Burlington.

Normy fiziologichnyh potreb naselennja Ukrai'ny v osnovnyh harchovyh rechovynah ta energii' (2017). Kyi'v (in Ukrainian).

Nriagu, J., Nam, D.H., Ayanwola, T.A., Dinh, H., Erdenebayar, E., Ochir, C., \& Bolormaa, T.A. (2011). High levels of uranium in groundwater of Ulaanbaatar, Mongolia. The Science of the total environment, $414.722-726$. doi:10.1016/j.scitotenv.2011.11.037

Nriagu, J.O. (1989). Occurrence and distribution of selenium. CRC Press, Boca Raton, FL.

Nutrient reference values for Australia and New Zealand including recommended dietary intakes. (2006). Canberra: National Health and Medical Research Council.

Papazjan, T., \& Golubkina, N. (2008). Selen v kormah sel'skohozjajstvennoj pticy. Pticevodstvo, 10, 45-46 (in Russian).

Papazjan, T.T., \& Golubkina, N.A. (2006). Selen v kormah sel'skohozjajstvennyh zhivotnyh, pticy, ryby. Vestnik RASHN, 2, 64-66 (in Russian).

Paton, N.D., Cantor, A.N., \& Pescatore, A.J. (2002). The effects of dietary selenium source and level on the uptake of selenium by developing chick embryos. Poultry Science, 81, 1548-1554. doi:10.1093/ps/81.10.1548

Perepjolkina, L.I. (2007). Korrekcija deficita selena u kur. Zootehnija, 12, 17-18 (in Russian).

Perrone, D., Monteiro, M., \& Nunes, J. (2015). Chapter 1 the chemistry of selenium. En: Selenium: chemistry, analysis, function and effects (Ed. Preedy, V.R.), 3-15. The Royal Society of Chemistry.

Petrovic, V., Boldizarova, K., Faix, S., Mellen, M., Arpasova, H., \& Leng, L. (2006). Antioxidant and selenium status of laying hens fid with diets supplemented with selenite or Se-yeast. Animal Feed Scienceand Technology, 15(3), $435-444$. doi:10.22358/jafs/66914/2006

Pilon-Smits, E.A.H., \& Quinn, C.F. (2010). Selenium metabolism in plants. In: Hell, R., \& Mendel, R. (eds), Cell Biology of Metal and Nutrients. Springer, Berlin, 225-241. doi:10.1007 / 978-3-642-10613-2_10

Plant, J.A, Kinniburgh, D.G, Smedley, P.L., Fordyce, F.M., \& Klinck, B.A. (2003). Arsenic and Selenium. Treatise on Geochemistry, 9, 17-66. doi:10.1016/B0-08-043751-6/09047-2.

Ponomarenko, Ju. (2007). Selen i jod v racionah brojlerov. Pticevodstvo, 4, 38-39 (in Russian).

Popenko, E.S. (2015). Osoblyvosti rozpodilu selenu u roslynnosti riznyh klimatychnyh zon. Poshukova ta ekologichna geohimija, 23-26 (in Ukrainian). 
Popenko, E.S., Samchuk, A.I., Ogar, T.V., \& Krasjuk O.P. (2012). Osoblyvosti rozpodilu vazhkyh metaliv ta selenu u g'runtah Pivdenno-Prysyvas'koi' akumuljatyvnoi' rivnyny (Ukrai'na). Geohimija ta rudoutvorennja, 31-32, 170-174 (in Ukrainian).

Prashanth, L., Kattapagari, K.K., Chitturi, R.T., Baddam, V.R., \& Prasad, L.K. (2015). A review on role of essential trace elements in health and disease. Journal of Dr. NTR University of Health Sciences, 4(2), 75-85. doi:10.4103/2277-8632.158577

Qazi, I.H., Angel, C., Yang, H., Pan, B., Zoidis, E., Zeng, C. J., Han, H., \& Zhou, G.B. (2018). Selenium, selenoproteins, and female reproduction: a review. Molecules (Basel, Switzerland), 23(12), 3053. doi:10.3390/molecules23123053

Qazi, I.H., Angel, C., Yang, H., Zoidis, E., Pan, B., Wu, Z., Ming, Z., Zeng, C. J., Meng, Q., Han, H., \& Zhou, G. (2019). Role of selenium and selenoproteins in male reproductive function: a review of past and present evidences. Antioxidants (Basel, Switzerland), 8(8), 268. doi:10.3390/antiox8080268

Rakov, O.V., \& Muz', V.A. (2019). Selen i zdorov'e cheloveka. Endokrinologija, 24(2), 178-186. doi:10.31793/1680-1466.2019.242.178

Ralston, N., Unrine, J., \& Wallschläger, D. (2008). Biogeochemistry and analysis of selenium and its species. Washington.

Rassolov, S.N., Glazunova, O.A., \& Eranov, A.M. (2008). Vlijanie selena i joda na himicheskij sostav mjasa sel'skohozjajstvennyh zhivotnyh i pticy, poluchavshih mikrodobavki selena i joda. Kormlenie sel'skohozjajstvennyh zhivotnyh i kormoproizvodstvo, 10, 67-70 (in Russian).

Ray, A.L., Semba, R.D., Walston, J., Ferrucci, L., Cappola, A.R., Ricks, M.O., Xue, Q.L., Fried, L.P. (2006). Low serum selenium and total carotenoids predict mortality among older women living in the community. The women's health and aging studies. Journal of Nutrition, 136, 172-176. doi:10.1093/jn/136.1.172

Rayman, M.P. (2008). Food-chain selenium and human health: emphasis on intake. British Journal of Nutrition, 100(2), 254-268. doi:10.1017/S0007114508939830

Rayman, M.P. (2012). Selenium and human health. Lancet, 379, 1256-1268. doi:10.1016 / S0140-6736 (11) $61452-9$

Reid, G.M. (2007). Sudden infant death syndrome: selenium administered above dietary needs stabilizes the electrocardiograms of subjects deprived of exercise stimuli to the brain. Med Hypotheses, 68(6), 1265-1267. doi:10.1016/j.mehy.2006.10.028

Reilly, C. (2006). Selenium in Food and Health. Springer Verlag Berlin Heidelberg, New York.

Reimann, C., \& Caritat, P. (1998). Chemical Elements in the Environment, Springer-Verlag, Heidelberg. doi:10.1007 / 978-3-64272016-1

Rocha, João B.T., Piccoli, B.C., \& Oliveira, C.S. (2017). Oliveirab Biological and chemical interest in selenium: a brief historical account. The Free Internet Journal for Organic Chemistry, 457-491. doi:10.3998/ark.5550190.p009.784

Roman, M., Jitaru, P., \& Barbante, C. (2014). Selenium biochemistry and its role for human health. Metallomics, 6(1), 25-54. doi:10.1039 / c3mt00185g

Rudenko, S.S., \& Dmitruk, B.M. (1999). Selen u gruntakh Bukovini. Visnik agrarnoi nauki, 7, 50-54 (in Ukrainan).

Schrauzer, G.N., \& Surai, P.F. (2009). Selenium in human and animal nutrition : Resolved and unresolved issues. Critical Reviews in Biotechnology, 29(1), 2-9. doi:10.1080 / 07388550902728261

Shestopalov, V.M., Ponomarenko, O.M., Moisejev, A.Ju., Samchuk, A.I., Moisejeva, N.P., \& Popenko E.S. (2011). Selen u pryrodnyh mineral'nyh vodah zahidnyh regioniv Ukrai'ny. Mineralogichnyj zhurnal, 33(2). 89-95 (in Ukrainian).

Shevchenko, S.A. (2006). Nakoplenie selena v jajcah i mjase kur-nesushek pri razlichnom soderzhanii ego $v$ racione. Sibirskij vestnik sel'skohozjajstvennoj nauki, 5, 96 (in Russian).

Shhelkunov, L.F., Dudkin, M.S., \& Golubkina, N.A. (2001). Biogeohimija mikrojelementa selena v Odesskom regione Ukrainy. Dovkillja ta zdorov'ja, 3, 20-24 (in Russian).

Shljapunova, E.V., \& Sergeev, G.M. (2010). Ekologicheskij monitoring: analiz i identifikacionnye priznaki prirodnyh pityevyh vod. Vestnik Nizhegorodskogo universiteta im. N.I. Lobachevskogo, 1, 116-121 (in Russian).

Skřivan, M., Bubancová, I., Marounek, M., \& Dlouhá, G. (2010). Selenium and a-tocopherol content in eggs produced by hens that were fed diets supplemented with selenomethionine, sodium selenite and vitamin E. Czech Journal of Animal Science, 55, 388-397. doi:10.17221/92/2010-CJAS

Sobolev, A.I. (2013). Soderzhanie selena v mjase molodnjaka raznyh vidov sel'skohozjajstvennoj pticy $v$ zavisimosti ot ego urovnja v kombikormah. Vestnik Kurskoj gosudarstvennoj sel'skohozjajstvennoj akademii, 1, 62-63 (in Russian).

Sobolev, A.I., \& Povoznikov, N.G. (2015). Vlijanie dobavok selena v kombikorma na kachestvo mjasa utjat. Molodoj uchenyj, 8.3, 56-59 (in Russian).

Sobolev, O., Gutyj, B., Petryshak, R., Pivtorak, J,. Kovalskyi, Y., Naumyuk, A,. Petryshak, O., Semchuk, I., Mateusz, V., Shcherbatyy, A., \& Semeniv B. (2018). Biological role of selenium in the organism of animals and humans. Ukrainian Journal of Ecology, $8(1), 654-665$. doi:10.15421/2017_263

Sobolev, O.I. (2009). Selen u kombikormah dlja sil's'kogospodars'koi' ptyci. Tehnologija vyrobnyctva i pererobky produkcii' tvarynnyctva : zbirnyk nauk. prac', 1, 25-27 (in Ukrainian).

Sobolev, O.I., Gutyj, B.V., Sobolieva, S.V., Borshch, O.O., Liskovich, V.A., Prystupa, O.I., Demus, N.V., Paladiychuk, O.R., Fedorovych, O.V., Fedorovych, E.I., Khariv, I.I., Vasiv, R.O., Levkivska, N.D., Leskiv, K.Y., \& Guta, Z.A. (2019). Chemical composition, energy and biological value of broiler chicken meat caused by various doses of selenium. Ukrainian Journal of Ecology, 9(4), 204-210. doi:10.15421/2019_799

Sobolev, A., Gutyj, B., Grynevych, N., Bilkevych, V., \& Mashkin, Y. (2017). Enrichment of meat products with selenium by introducing mixed feeds for birds in their compound. Regulatory Mechanisms in Biosystems, 8(3), 417-422. doi:10.15421/021764

Solovyev, N., Drobyshev, E., Bjørklund, G., Dubrovskii, Y., Lysiuk, R., \& Rayman, M.P. (2018). Selenium, selenoprotein P, and Alzheimer's disease: Is there a link? Free Radical Biology and Medicine, 127(1), 124-133. doi:10.1016/j.freeradbiomed.2018.02.030 
Suchkov, B.P., \& Bardov,V.G. (1999). Rozpovsjudzhennja mikroelementa selenu v ob'jektah navkolishn'ogo seredovishha na teritorii' Ukrai'ni ta jogo vplyv na zdorov'ja naselennja. Problemi mediciny, 5, 55-59 (in Ukrainian).

Suchy, P., Strakova, E., \& Herzig, I. (2014). Selenium in poultry nutrition: a review. Czech Journal of Animal Science, 59(11), 495503. doi:10.17221/7730-CJAS

Sun, G.X., Meharg, A.A., Li, G., Chen, Z., Yang, L., Chen, S.C., \& Zhu, Y.G. (2016). Distribution of soil selenium in China is potentially controlled by deposition and volatilization?. Scientific reports, 6, 20953. doi:10.1038/srep20953

Surai, P.F. (2002). Selenium in poultry nutrition: a new look at an old element. 2. Reproduction eggs and meat quality and practical applications. World's Poultry Science, 58, 431-450. doi:10.1079/wps20020032

Surai, P.F. (2006). Selenium in nutrition and health. University Press, Nottingham.

Surai, P.F. (2007). Ispol'zovanie "Sel-Pleksa" dlja uluchshenija zdorov'ja zhivotnyh i ljudej. Efektivne ptahivnictvo, 2, 2-28 (in Russian).

Surai, P.F. (2018). Selenium-enriched eggs and meat. In: Surai, P.F. (ed). Selenium in poultry nutrition and health, $279-307$. doi:10.3920/978-90-8686-865-0_6

Surai, P.F., \& Dvorskaja, Ju.E. (2003). Organicheskij selen i ego rol' v kormlenii matochnogo pogolov'ja kur. Ptahivnictvo, 53, 324329 (in Russian).

Sychov, M.Yu., Holubiev, M.I., Kovalchuk, V.V., Pozniakovskyi, Yu.V., Holubieva, T.A., \& Makhno, K.I. (2017). Valine needs in growing quails. Ukrainian Journal of Ecology, 7(3), 180-185.

Tan, J., Zhu, W., Wang, W., Li, R., Hou, S., Wang, D., \& Yang, L. (2002). Selenium in soil and endemic diseases in China. Science of the Total Environment, 284(1-3), 227-235. doi:10.1016/s0048-9697(01)00889-0

Tapiero, H., Townsend, D.M., \& Tew, K.D. (2003). The antioxidant role of selenium and seleno-compounds. Biomed Pharmacother, 57(3-4), 134-144. doi:10.1016/s0753-3322(03)00035-0

Temmerman, L.D., Waegeneers, N., Thiry, C., Laing, G.D., Tack, F., \& Ruttens, A. (2014). Selenium content of Belgian cultivated soils and its uptake by field crops and vegetables. Science of the Total Environment, 468-469, 77-82. doi:10.1016/j.scitotenv.2013.08.016

Thomson, C. (2004). Assessment of requirements for selenium and adequacy of selenium status: a review. European Journal of Clinical Nutrition, 58, 391-402. doi:10.1038/sj.ejcn.1601800

Tinggi, U. (2003). Essentiality and toxicity of selenium and its status in Australia: a review. Toxicology Letters, 137(1-2), 103-110. doi:10.1016/s0378-4274 (02) 00384-3

Tishenkov, A.N., Grineva Je.V., Chernoshhjokov E.G. Mel'nikova, S.V., \& Shevjakov, A.N. (2006). Selen v racionah brojlerov. Sbornik nauchnyh trudov VNITIP, 81, 80-90 (in Russian).

Tutel'jan, V.A. (2009). O normah fiziologicheskih potrebnostej v jenergii i pishhevyh veshhestvah dlja razlichnyh grupp naselenija Rossijskoj Federacii. Voprosy pitanija, 78(1), 4-15 (in Russian).

Whanger, P.D. (1998). Metabolism of selenium in humans. Trace Element in Experimental Medicine, 11, 227-240. doi:10.1002/(SICI)1520-670X(1998)11:2/3<227::AID-JTRA13>3.0.CO;2-T

WHO/FAO/IAEA. (1996).Trace Elements in Human Nutrition and Health. Geneva: World Health Organization.

Winkel, L.H., Vriens, B., Jones, G.D., Schneider, L.S., Pilon-Smits, E., \& Bañuelos, G.S. (2015). Selenium cycling across soil-plantatmosphere interfaces: a critical review. Nutrients, 7(6), 4199-4239. doi:10.3390/nu7064199

World Health Organization. (2011). Selenium in drinking-water background document for development of WHO Guidelines for drinking-water quality. WHO Press, Geneva.

Yao, Y., Pei, F., \& Kang, P. (2011). Selenium, iodine, and the relation with Kashin-Beck disease. Nutrition, 27(11-12), 1095-1100. doi:10.1016/j.nut.2011.03.002

Yu, N., Han, F., Lin, X., Tang, C., Ye, J., \& Cai, X. (2016). The association between serum selenium levels with rheumatoid arthritis. Biological Trace Element Research, 72, 46-52. doi:10.1007/s12011-015-0558-2

Zachara, B.A., Szewczyk-Gole, K., Tyloch, J., Wolski, Z., Szylberg, T., Stepien, S., Kwiatkowski, S., Bloch-Boguslawska, E., \& Wasowicz, W. (2005). Blood and tissue selenium concentrations and glutathione peroxidase activities in patients with prostate cancer and benign prostate hyperplasia. Neoplasma, 52, 248-254.

Zajcev, V.A., But'ko, Z.T., Zastenskaja, I.A., \& Mohort E.G. (2005). Ocenka i korrekcija selenovogo statusa organizma cheloveka v razlichnyh jekologicheskih uslovijah prozhivanija. Minsk (in Russian).

Zhang, H., Feng, X., Jiang, C., Li, Q., Liu, Y., Gu, C., Shang, L., Li, P. \& Larssen, T. (2014). Understanding the paradox of selenium contamination in mercury mining areas: high soil content and low accumulation in rice. Environmental Pollution. 188, 27-36. doi:10.1016/j.envpol.2014.01.012

Zhao, C., Ren, J., Xue, C., \& Lin, E. (2005). Study on the relationship between soil selenium and plant selenium uptake. Plant Soil, 277, 197-206. doi:10.1007/s11104-005-7011-9

\section{Citation:}

Sobolev, O.I., Gutyj, B.V., Sobolieva, S.V., Borshch, O.O., Nedashkivsky, V.M., Kachan, L.M., Karkach, P.M., Nedashkivska, N.V., Poroshinska, O.A., Stovbetska, L.S., Emelyanenko, A.A., Shmayun, S.S., Guta, Z.A. (2020). Selenium in natural environment and food chains. A Review.

Ukrainian Journal of Ecology, 10(4), 148-158.

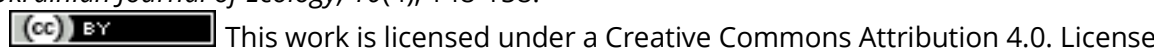

